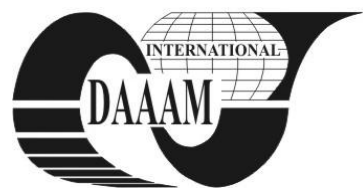

Annals of DAAAM for 2011 \& Proceedings of the 22nd International DAAAM Symposium, Volume 22, No. 1, ISSN 1726-9679 ISBN 978-3-901509-83-4, Editor B. Katalinic, Published by DAAAM International, Vienna, Austria, EU, 2011 Make Harmony between Technology and Nature, and Your Mind will Fly Free as a Bird Annals \& Proceedings of DAAAM International 2011

\title{
A CONTROL SYSTEM FOR MOBILE FORESTRY CABLEWAY WITH HYDROSTATIC DRIVES PART 2
}

\author{
KLIMA, B[ohumil]; HUTAK, P[etr] \& PROCHAZKA, P[etr]
}

\begin{abstract}
This paper deals with mobile forestry cableways. The modern cableways must meet many requirements. Some of them are safety, reliability, handling ergonomics and comfort, operating performance, operating costs etc. Wood logging problems and technology are quite complex and are described in many publications focused on this technical area (Freedman et al., 1995), (Goldenberg et al., 1995), (Junmei et al., 2007) and (Papadopoulos \& Sarkar, 1997). Only basic principles are described in this paper and the main part is focused on driving system and control requirement of concrete cableway Larix H3 650. Mechanical system is described in the paper "A Control System for Mobile Forestry Cableway with Hydrostatic Drives part 1" (This paper is presented at this conference too) Key words: forestry cableway, winding drums control, hydrostatic drives
\end{abstract}

\section{INTRODUCTION}

There exist many configurations from tractor-mounted winches used to extract timber by skidding on ground too difficult for horse extraction up to modern sophisticated systems constructed as a special trailor or on a truck, which are temporarily built in forest to extract timbers from a certain space in forest. One of them is Larix H3 650P - trailor version or Larix H3 650A - truck version.

Main parts of such cableway are mobile chassis (trailor or truck), hydraulic foldaway tower with pulleys, a set of winding drums with cables and their driving system. A carriage cooperates with the cableway. The number of winch drums depends on required configuration of logging and on carriage system requirements. Larix $\mathrm{H} 3650 \mathrm{P}$ has three operating drums (skyline, mainline, haul-back line), four anchor drums and one drum for lightweight textile straw line.

\section{USER INTERFACE AND HANDLING ERGONOMICS}

It is well known that the wood logging is a heavy and dangerous job. Workers are exposed to many stress conditions - carrying heavy accessories in difficult terrain, noise of forestry machinery, following safety instructions and safety distances during tree cutting and wood transporting, weather etc. Therefore the machinery must be designed according to many safety standards. The basic approaches of the whole cableway system designing are robustness, reliability, safety managing of failure modes, predictable and safe behavior and responses in all operating modes and foolproof handling.

Operators use two types of user interfaces. One of them is panel with LCD and keypad and the second is a radiofrequency remote control station eventually cable control station with the same functionality.

The user panel serves for parameters setting, diagnostics information, self-test results displaying and in standard operation modes it provides cableway state information: current operating mode, active command station, issued command, hydraulic loops pressures, engine speed, moving cable or carriage speed, carriage position on the track etc.

Three remote/cable control stations can be connected into the control system. Standard equipment are two radio-controller stations and one reserve cable-controller in case of failure one of the radio-controller. User panel of remote/cable stations contains a set of binary controls ( 2 three position levers, 1 five position cruise lever and 4 buttons - all of them have automatically a return into the zero position). It means twelve bits information needs to be transferred via radio.

Basic concept of individual stations control priority is following: Two control stations are usually used. One of them is used by the operator in forest which binds and extracts timbers and sends them in to the stock-yard place in automatic traversing mode. The second one is used by the operator which drops down the timbers and sends carriage back also in automatic mode. Only one of these stations can control the cableway. Only if the one gives off control priority (priority is free for takeover) then any other station can take it up. Automatic traversing mode presents the same state as when control priority is free for taking up.

Handling ergonomics strategy needs except issuing cableway commands for individual cableway operating modes also ability to do all other commands by these remote controllers including operating mode changing, engine start and stop, control priority giving of / taking up etc. All operations are done without coming close to keypad/LCD panel. For these purposes complete combinations set of controls for particular commands is defined. Some of them are issued immediately after pushing proper control/controls combination, the others controls combinations must be kept at least some defined time. Speed setting is executed by simultaneous keeping appropriate command control and control for speed increasing/decreasing. Speed increases/decreases proportionally to the time during which the combination of commands is simultaneously kept.

The next aspect in cableway safety is possibility of unwanted touching of controls. For dangerous operations two controls combinations eventually timed two controls combinations are defined.

\section{CONTROL COMPUTER HARDWARE}

Previous text simply describes requirement for controlling computer. The control computer is purpose-built microprocessor system. Case of the computer contains keypad/LCD panel shown in Fig. 1. Three connectors for connecting remote/cable control stations are on the front side and one main connector connecting whole remaining cableway system is on the back side. The computer hardware is designed according to strong mechanical and vibration shock durability requirements and for enhanced climatic and temperature ranges.

Block scheme of controlling computer is shown in Fig. 2. The system is based on Freescale 16-bits digital signal controller MC56F8366 which provides enough RAM and flash memory, I/O pins and peripheries (*** 2009). All next I/O circuits are built on a PCB according to Fig. 2 . 


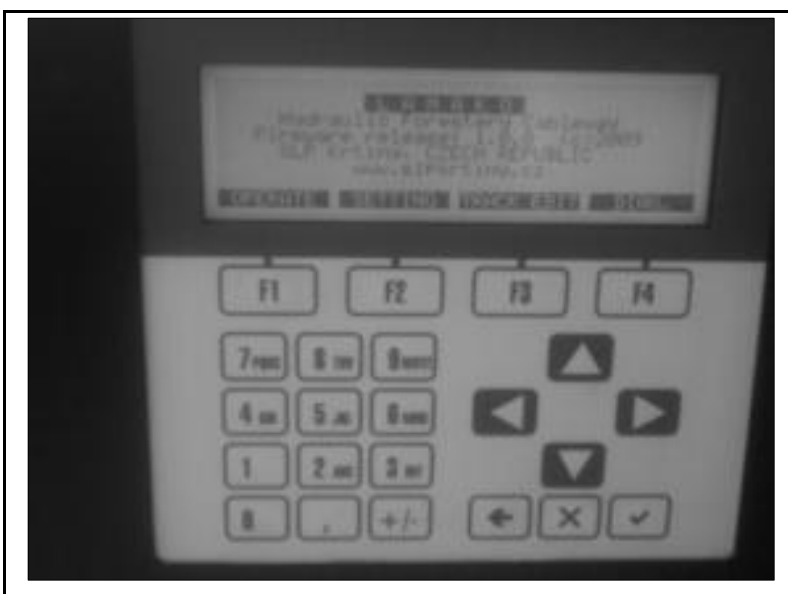

Fig. 1. Control computer front side view with graphic LCD and membrane keypad

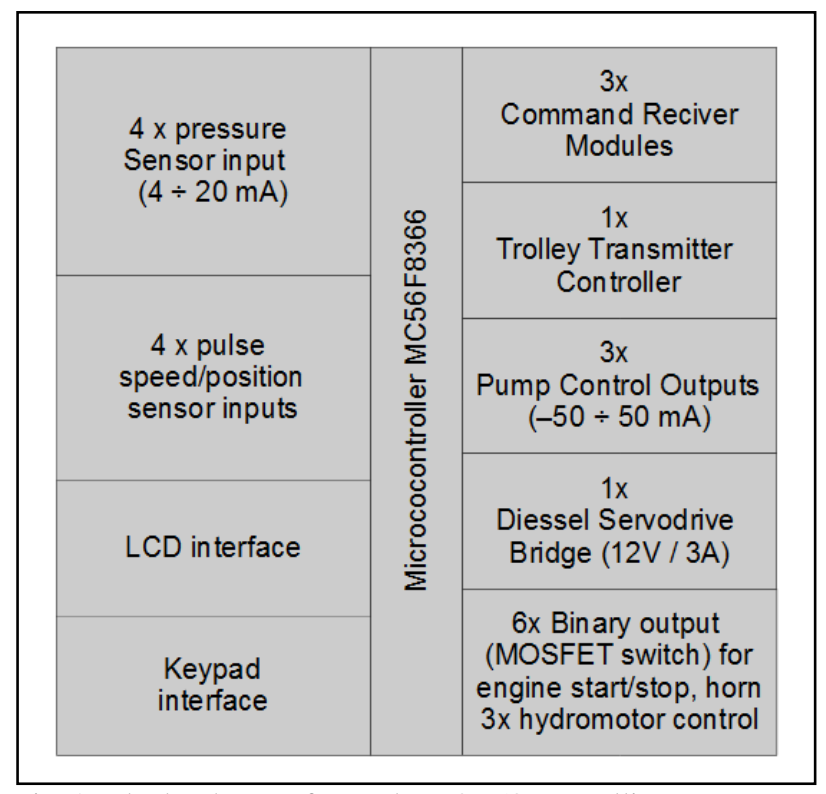

Fig. 2. Block scheme of Lamako H3 650 controlling computer

\section{OPERATING MODES}

Whole operation of the cableway is not only logging, but there must be modes for mounting of the cableway, skyline straining/operating position setting and track points setting.

Logging mode allows traversing of carriage on skyline manually or in automatic mode, pulling up and putting down a timber. Automatic traversing represents possibility for operators to set speed and switch-on automatic traversing mode without necessity of keeping command buttons all traversing time on remote radiofrequency controller. The carriage runs to a point of automatic stop or any operator can take manual control again. Similar automatic mode exists for slack pulling when timber binding operator goes with slack through complicated terrain also without necessity keeping any button. In operating mode it is also possible to change position of automatic stop points at begin and at the end of track according to operator's needs.

Mounting mode allows an independent control of individual winch (roll up or unroll). Mounting procedure begins by going through track with auxiliary lightweight textile straw line. This line is used for pulling out first steel rope too. And then remaining ropes are pulled out. The straw line is controlled independently on control system by manual hydraulic controller. The controlled steel rope winch hydro-motor is switched to high force mode and two remaining winches are switched into high speed mode to assure low force necessary for pulling out of cable.

Skyline straining mode is used for setting operating tension of skyline or for setting operating position. The task of skyline drive is to keep the winch in constant position and to limit maximal tension (pressure) in cable by unwinding the drum when skyline is overloaded. When overloading passes over the skyline drum returns to the set position. The active limiting of skyline tension is an important advantage of Larix H3 650 contrary to other cableway manufacturers. The usual solution is tensioning skyline by auxiliary hydro-motor and the tension during operation is kept by mechanical brake. Tension limiting is assured by breaking force setting. The passive skyline tension limiting has a disadvantage in case of its overloading when it is necessary to stop logging and to taighten it manually again.

Track points setting mode is used to set a safety point near cableway tower for avoiding carriage crashes during logging. The control system doesn't allow going over this point in the logging mode. In this mode it is also possible to set skyline support points on which traversing speed is limited to the value set by parameter. Skyline supports are special parts hanged up on track surrounding trees. These supports hold skyline up on high in places where tensioned skyline doesn't assure carriage traversing in sufficient height above the terrain (for example when the track goes over a hill).

\section{CONCLUSION}

This paper deals with issue of user interface and handling ergonomics, control computer hardware system and various modes of operation of the forestry cableways.

Circuits for remote diagnostics of the system using the GSM module for the entire system of the forestry cableways will be developed and implemented.

\section{ACKNOWLEDGEMENTS}

The contribution was partially supported by projects CZ.1.05/2.1.00/01.0014 of the Ministry of Education and MSM 0021630516 of the Ministry of Education, Youth and Sports of the Czech Republic.

\section{REFERENCES}

Freedman, P. Papadopoulos, E. Poussart, D. Gosselin, C. Courteau, J. (1995). Application of Robotic Technologies to Forestry Equipment, Electrical and Computer Engineering, Vol.2, (September 1995), (1140 - 1143), ISSN 0840-7789

Goldenberg, A.A. Wiercienski, J. Kuzan, P. Szymczyk, C. Fenton, R.G. Shaver, B. (1995). A remote manipulator for forestry operation, Robotics and Automation IEEE Transactions, Vol. 11, No. 2, (April 1995), (185 - 197), ISSN 1042-296X

Junmei Z, Wenbin L, Chao S, Deming W, Chua, P.S.K., Tan F.L. (2007). Development of a CPLD Based Wireless Remote Control System of Pruning Machine for Plantation Forest, Proceedings of Computer Supported Cooperative Work in Design, 2007. CSCWD 2007, Melbourne, Australia, ISBN 1-4244-0963-2, Weiming Shen (Ed.), pp. 1078 - 1081, Melbourne

Papadopoulos, E. Sarkar, S. (1997). The dynamics of an articulated forestry machine and its applications, Proceedings of Robotics and Automation IEEE nternational Conference, Vol.1., ISBN 0-7803-3612-7, pp. 323 - 338

*** (2005). http://www.freescale.com - 56F8366/56F8166 16bit Digital Signal Controllers, Data Sheet Preliminary Technical Data, Acesses on: 2009-11-15 